\title{
Evaluation of Evaporation Paradox at Tharandt
}

\author{
Antensay Mekoya* \\ Ethiopia Environment and Forest Research Institute, Bahir Dar Environment and Forest Research Center, Ethiopia
}

Submission: April 24, 2020; Published: May 12, 2020

*Corresponding author: Antensay Mekoya, Ethiopia Environment and Forest Research Institute, Bahir Dar Environment and Forest Research Center, P.O. Box: 2128 Bahir Dar, Ethiopia

\section{Graphical Abstract}

In the past decades evaporation of water has been generally decreasing in most parts of the world with increasing air temperature, which is called the 'evaporation paradox'. At Tharandt, Germany from 2004 to 2013 on annual basis the so-called 'evaporation paradox' had not existed because air temperature had not shown increasing trend. However, when we exclude Class A pan evaporation ( $E_{p}$ ) in to consideration, indeed, it had existed on the summer half-year (Figure 1).



Figure 1: Summer half-year evaporation paradox at Tharandt.

\section{Highlights}

a) Consideration of the warmer times of a year in a cold climate site.

b) Use of methods very suitable for a very humid climate.

c) Consideration of both measured and estimated evaporation schemes.

\section{Abstract}

In the past decades pan water evaporation has been generally decreasing in most parts of the world with increasing air temperature; which is called the 'evaporation paradox'. In this article, evaporation paradox was checked at Tharandt, Germany for the years from 2004 to 2013 . The annual as well as summer half-year trends of air temperature as well as Class A pan evaporation ( $\mathrm{E}_{\mathrm{p}}$ ), potential evapotranspiration (PET), and reference evapotranspiration (ET ) was analyzed using liner regression model. Generally, the so-called 'evaporation paradox' had not existed at Tharandt on annual basis. Because although PETs and ET ${ }_{0}$ had shown annual as well as summer half-year decreasing trends, air temperature had not shown increasing annual trends. However, when we had not considered $\mathrm{E}_{\mathrm{p}}$, indeed, it had existed on the summer half-year based on PETs and $\mathrm{ET}_{0}$ estimates. Decreasing trend of shortwave or solar radiation and increasing trend of relative air humidity might have caused the decreasing trends of PETs and ET. The summer half-year $\mathrm{E}_{\mathrm{p}}$ had shown nearly constant trend over the ten years; however, the cause for the nearly constant trend of summer half-year $\mathrm{E}_{\mathrm{p}}$ was not understood. Also, when 2013 was excluded, the annual as well as the summer half-year trends of PETs remained decreasing; however, the summer half-year trend of $\mathrm{E}_{\mathrm{p}}$ and $\mathrm{ET}_{\mathrm{o}}$ showed changes. Moreover, in all cases, the trends were not statistically significant. Thus, if data is available, using more than ten years of data is needed to evaluate the exact trends of $\mathrm{ET}_{\mathrm{o}}$ and $\mathrm{E}_{\mathrm{p}}$.

Keywords: Evaporation paradox; Class A pan evaporation; Potential evapotranspiration; Reference evapotranspiration; Tharandt

Abbreviations: E : Class A Pan Evaporation; SHY: Summer Half-Year (April-September); PETs: Potential Evapotranspiration (PET) estimated according to Haude, Wendling, and Penman; $\mathrm{E}_{\mathrm{p}}$ : Evaporation Schemes: $\mathrm{ET}_{\mathrm{o}}$ : Reference Evapotranspiration 


\section{Introduction}

A literature review of different articles [1-5] for the past decades had shown that pan water evaporation has been generally decreasing in most parts of the world instead of increase with increased air temperature, which is called the 'evaporation paradox' or 'evaporation fallacy' [6]. Roderick et al. [1] have made comprehensive study on the trend of pan evaporation conducted by large numbers of international studies in many parts of the world such as USA, Former Soviet Union, India, China, Australia,

Thailand, New Zealand, Tibetan Plateau, Israel, Turkey, Canada, Kuwait, Ireland, and UK for different periods (ranging from 1948 to 2005) and for different sites (ranging from 1 site to 746 sites).

According to Roderick et al. [1] many countries maintained standardized networks of evaporimeters where the long-term data can be used to determine trends in evaporative demand. However, there may be limitations such as changes in observation practice, instrument location, the environment surrounding the pan (e.g., buildings or trees obstructing the airflow), etc. With those caveats in mind, when averaged over a large number of pans, pan evaporations have indicated widespread declines over 30 to 50 years [1]. According to Roderick et al. [1], an overall trend of $-2 \mathrm{~mm} \mathrm{a}^{-2}$ equivalently $-0.16 \mathrm{Wm}^{-2} \mathrm{a}^{-1}$ was reasonably typical (Roderick et al. [1] (Table 1)).

Table 1: Average air Temperature (in ${ }^{\circ} \mathrm{C}$ ) at Tharandt, Germany.

\begin{tabular}{|c|c|c|c|c|c|c|c|c|c|c|c|c|c|c|}
\hline & Jan & Feb & Mar & Apr & May & Jun & Jul & Aug & Sep & Oct & Nov & Dec & SHY & Annual \\
\hline 2004 & -2.3 & 1.9 & 3.7 & 9.1 & 11.1 & 15.3 & 17.2 & 18.4 & 13.5 & 9.9 & 4 & 0.9 & 14.1 & 8.6 \\
\hline 2005 & 1.5 & -2.1 & 2.6 & 9.2 & 12.9 & 15.5 & 18.3 & 15.9 & 14.9 & 10.8 & 3.6 & 0.2 & 14.5 & 8.6 \\
\hline 2006 & -3.8 & -1.6 & 1.1 & 8.4 & 12.9 & 16.4 & 21.6 & 15.8 & 16.6 & 11.5 & 6.4 & 3.8 & 15.3 & 9.1 \\
\hline 2007 & 4 & 3.8 & 6.1 & 10.3 & 14.5 & 18 & 18.1 & 17.2 & 12.4 & 8 & 2.9 & 1.1 & 15.1 & 9.7 \\
\hline 2008 & 3.3 & 4.1 & 4.1 & 7.6 & 14 & 17.1 & 18.4 & 17.7 & 12.7 & 9.4 & 4.8 & 1 & 14.6 & 9.5 \\
\hline 2009 & -4 & 0.4 & 4.5 & 12.1 & 13.2 & 14.7 & 18.5 & 18.4 & 14.8 & 7.5 & 6.5 & -0.4 & 15.3 & 8.9 \\
\hline 2010 & -5 & -1.1 & 3.7 & 8 & 11.1 & 16 & 19.8 & 17.4 & 12 & 7.3 & 4.7 & -5.2 & 14.1 & 7.4 \\
\hline 2011 & -0.2 & -1 & 4.7 & 11.3 & 13.7 & 17.4 & 16.5 & 18.4 & 15.6 & 9.8 & 4.1 & 3.2 & 15.5 & 9.5 \\
\hline 2012 & 1.6 & -3.7 & 6.7 & 8.8 & 14.5 & 16.1 & 18.6 & 18.7 & 14.2 & 8.2 & 4.5 & 0 & 15.2 & 9 \\
\hline 2013 & -0.9 & -0.9 & -0.9 & 8.6 & 12.6 & 15.9 & 19.4 & 18.1 & 12.9 & 10.6 & 4.2 & 2.9 & 14.6 & 8.5 \\
\hline Avg & -0.6 & 0 & 3.6 & 9.3 & 13.1 & 16.2 & 18.6 & 17.6 & 14 & 9.3 & 4.6 & 0.7 & 14.8 & 8.9 \\
\hline
\end{tabular}

On the other hand, pan evaporation in the semiarid Loess Plateau in China showed a unique and significant upward trend, with a normalized value from approximately -1 to 1 [2]. Zhang et al. [2] have also shown that although they have different time-length series, pan evaporation in other regions of the world exhibited clear decreasing trends. Thus, pan evaporation trends are not entirely consistent in the context of increased air temperature. "It may decrease in most areas but can increase in some areas" [2]. In another similar study, Abtew et al. [4] recommended studying pan evaporation trend in every region to evaluate the validity of the trend and water management implications.

Therefore, in this article whether this decreasing trend of pan evaporation has been evident or not in a very humid city (Tharandt, Germany) is investigated together with trends of reference and potential evapotranspiration.

\section{Data and Methodology}

The study area was Tharandt, Germany (altitude: 220ma.s.l., latitude: 5058'42.06" N, longitude: $13^{\circ} 34^{\prime} 52.69^{\prime \prime} \mathrm{E}$ ). Ten years (01.01.2004 to 31.12.2013) daily and ten-minutes climate data of Tharandt meteorological station was the basis of the data set. See
Figure 2 for the 2004-2013 average values of part of the data set.

The pan used for measurement of pan evaporation was the World Meteorological Organization (WMO) standard Class A pan evaporimeter. Mainly the following data were used:

a) Air temperature in ${ }^{\circ} \mathrm{C}$ at 2 p.m.,

b) Relative humidity (RH) in \% at 2p.m.,

c) Wind speed in $\mathrm{m} \mathrm{s}^{-1}$ at $3 \mathrm{~m}$ above ground $\left(\mathrm{u}_{3}\right)$,

d) Precipitation in $\mathrm{mm}(\mathrm{P})$ (measured at 7a.m.),

e) Precipitation in $\mathrm{mm}(\mathrm{RF})$ (automatic measurement at midnight),

f) Global or shortwave radiation in $\mathrm{Wm}^{-2}$ at $3 \mathrm{~m}$ above ground $\left(R_{s}\right)$; in Figure 3, half of the shortwave radiation is shown,

g) Water table height in mm (automatic measurement at every 10-minutes interval using pressure sensor instrument),

h) Maximum air temperature in ${ }^{\circ} \mathrm{C}\left(\mathrm{T}_{\max }\right)$,

i) Minimum air temperature in ${ }^{\circ} \mathrm{C}\left(\mathrm{T}_{\min }\right)$, 
j) Maximum relative air humidity in $\%$ at $2 \mathrm{~m}$ above ground $\left(\mathrm{RH}_{\max }\right)$,

k) Minimum relative air humidity in $\%$ at $2 \mathrm{~m}$ above ground $\left(\mathrm{RH}_{\text {min }}\right)$,

l) Water level height values in mm (7a.m. to 7a.m. of the next day), m) Air temperature in ${ }^{\circ} \mathrm{C}(\mathrm{T}) ; \mathrm{T}=\left(\mathrm{T}_{\max }+\mathrm{T}_{\min }\right) / 2$,

n) Relative air humidity in \% (RH); $\mathrm{RH}=\left(\mathrm{RH}_{\max }+\mathrm{RH}_{\min }\right) / 2$,

o) Wind speed in $\mathrm{m} \mathrm{s}^{-1}$ at $2 \mathrm{~m}$ above ground $\left(\mathrm{u}_{2}\right) ; \mathrm{u}_{2}$ was calculated from $\mathrm{u}_{3}$ using the equation of Allen et al. [7].

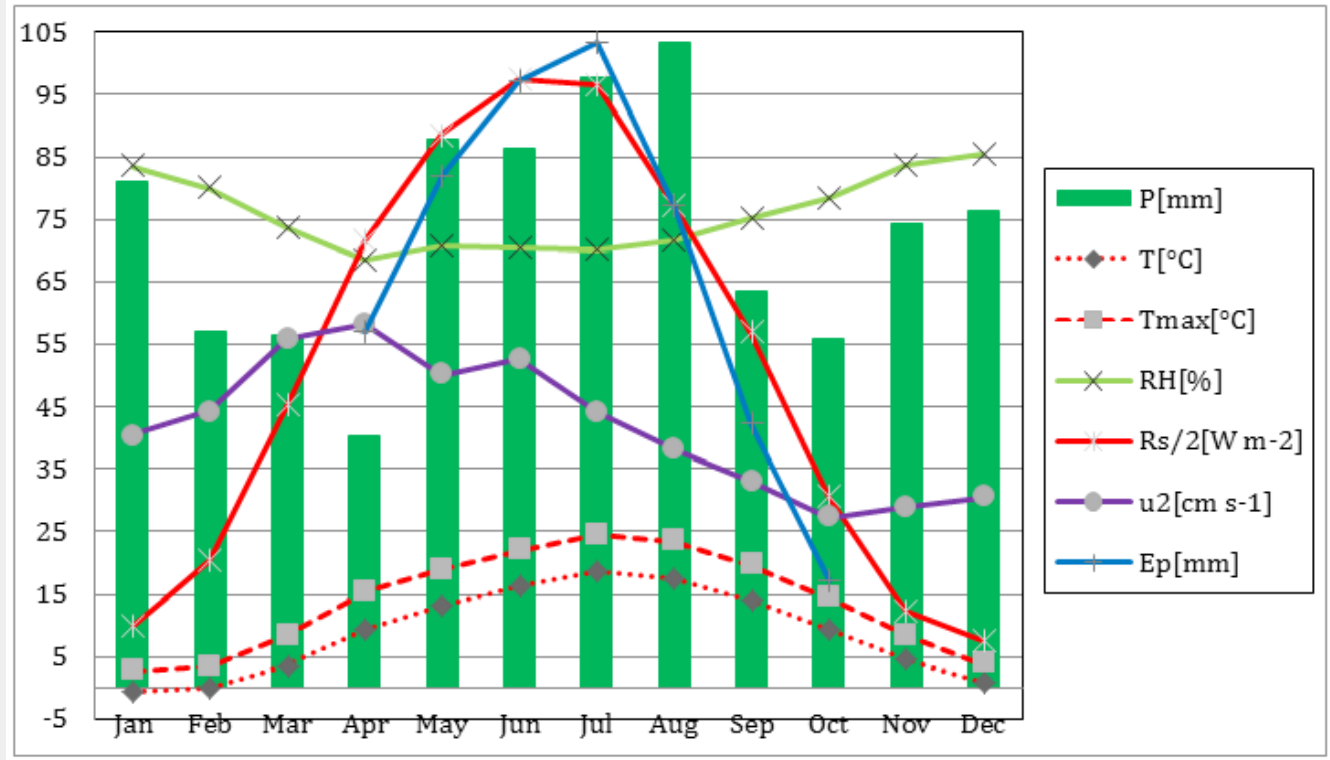

Figure 2: Some of the meteorological parameters used for the study at Tharandt (2004-2013).
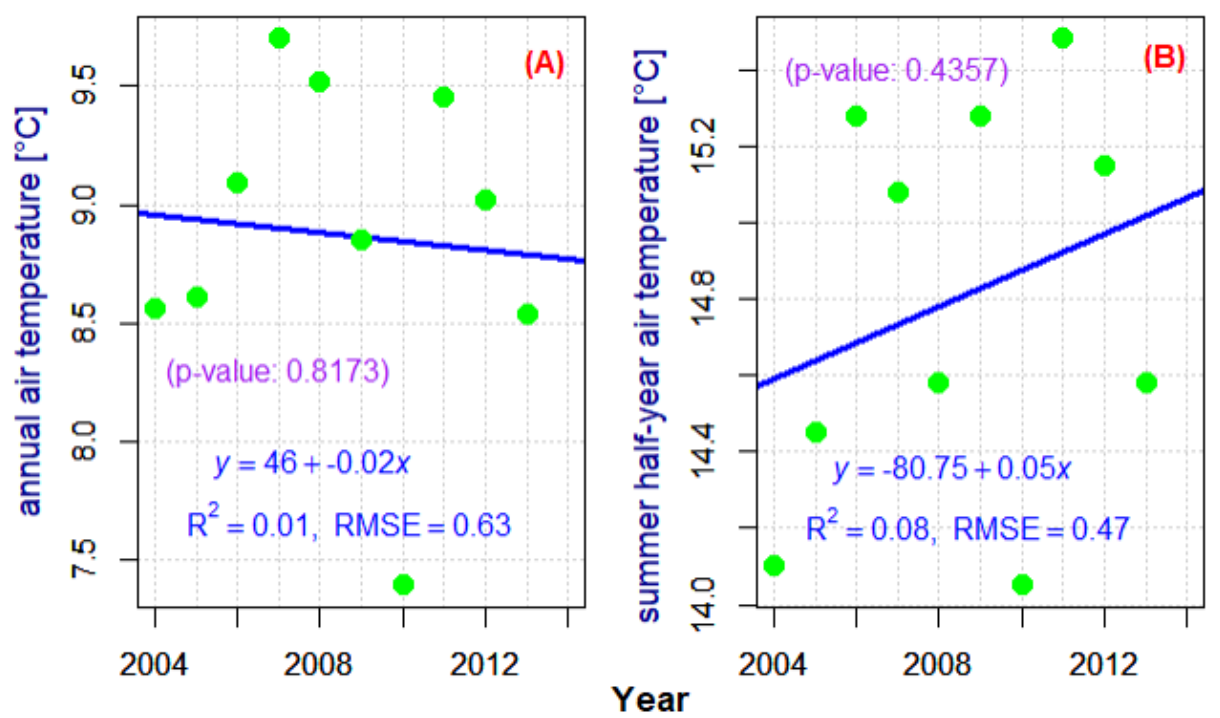

Figure 3: Annual and summer half-year air temperature trend.

Potential evaporation (PET) was estimated using three methods:

a. Haude (2005) [8], b. Wendling (1991) [9], and

c. Penman (1963) [10]. 
Whereas, reference evapotranspiration (ET ${ }_{0}$ ) was estimated according to Allen et al. [7]. Class A pan evaporation ( $\left.E_{p}\right)$ was calculated for the summer half-year as described in Antensay et al. [11]. Then, trends of evaporation schemes were analyzed using linear regression model and evaluated using error evaluation statistics such as $\mathrm{R}^{2}$ and RMSE [12]. Finally, a significant test was performed using $\mathrm{p}$-value at $95 \%$ confidence interval.

\section{Result and Discussion}

\section{Evaluation of annual evaporation paradox}

For evaporation paradox to exist, the temperature should show an increasing trend. However, the annual air temperature showed slightly decreasing trend; decresed about $0.25{ }^{\circ} \mathrm{C}$ over the ten years (see Figure 3 'A'). Therefore, from 2004 to 2013 evaporation paradox did not exist at Tharandt on annual basis inspite of the fact that PETs and ET ${ }_{0}$ had shown an annual decreasing trends (not shown).

On the other hand, the summer half-year (SHY) air temperature showed increasing trend; showed an increse of about $0.5{ }^{\circ} \mathrm{C}$ over the ten years (see Figure 3 'B'). Therefore, from 2004 to 2013 evaporation paradox could exist at Tharandt on the SHY basis if PETs, $\mathrm{ET}_{\mathrm{o}}$ and $\mathrm{E}_{\mathrm{p}}$ had showed a SHY decreasing trends.

\section{Evaluation of summer half-year evaporation paradox}

The summer half-year (SHY) total PET according to Haude, Wendling, and Penman showed decreasing trends; decreased by about 45, 30, and 33 millimeters over the ten years, respectively (see Figure 4). Similarly, the SHY total ET showed decreasing trend; decreased by about $14 \mathrm{~mm}$ over the ten years (see Figure 5 ' $\mathrm{A}$ '). However, the SHY total $\mathrm{E}_{\mathrm{p}}$ showed approximately constant trend (see Figure 5 ' $\mathrm{B}$ ').



Figure 4: Summer half-year potential evapotranspiration trends.
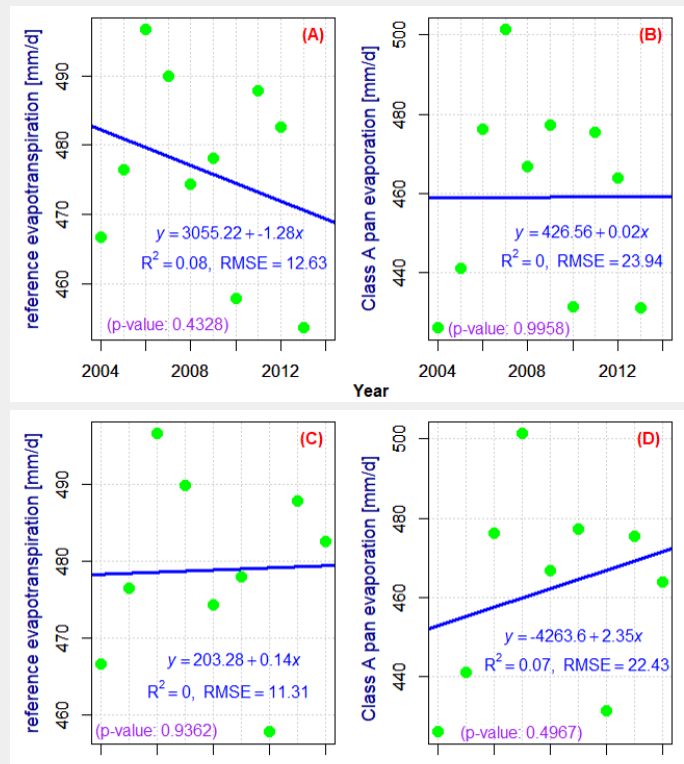

$2004200620082010 \quad 2012$

$2004 \quad 20062008 \quad 20102012$

Figure 5: Summer half-year reference evapotranspiration and Class A pan evaporation trends from 2004 to 2013 (figures 'A' \& 'B') and from 2004 to 2012 (figures 'C' \& 'D'). 
When only one year 2013 was excluded, the SHY PETs showed decreasing trends again (not shown). However, the SHY total ET showed negligibly very weak increasing trend; increased by about $2 \mathrm{~mm}$ over the ten years (see Figure 5 ' $\mathrm{C}$ '). Whereas, the SHY total $\mathrm{E}_{\mathrm{p}}$ showed increasing trend; increased by about $20 \mathrm{~mm}$ over the ten years (see Figure 5 'D').

At Tharandt from 2004 to 2013, the annual trend of shortwave or solar radiation $\left(\mathrm{R}_{\mathrm{s}}\right)$ had shown a decreasing trend; note that evaporation or evapotranspiration at Tharandt was mainly deriven by $\mathrm{R}_{\mathrm{s}}$. Similarly, the annual trend of relative air humidity $(\mathrm{RH})$ and wind speed at $2 \mathrm{~m}\left(\mathrm{u}_{2}\right)$ had shown increasing and decreasing trends, respectively; note the inverse relationship between evaporation and $\mathrm{RH}$; note that the effect of $\mathrm{u}_{2}$ in deriving evaporation or evapotranspiration at Tharandt was negligibly too low. The summer half-year trend of $\mathrm{R}_{\mathrm{s}^{\prime}} \mathrm{RH}$ and $\mathrm{u}_{2}$ was the same as the annual trend except that the summer half-year air temperature had shown an increasing trend. These could be the possible causes for the decreasing annual as well as summer halfyear trends of $\mathrm{ET}_{\mathrm{o}}$ and PETs.

However, the cause for the nearly constant or very slightly increasing trend of summer half-year $\mathrm{E}_{\mathrm{p}}$ was not understood. Note however that $\mathrm{E}_{\mathrm{p}}$ was mainly driven by solar radiation and vapor pressure deficit ( $\mathrm{T}$ and $\mathrm{RH}$ ). Note also that the correlation between $E_{p}(n=1709)$ as well as $R_{s}(n=1830)$ with air temperature was low $\left(R^{2} \leq 0.34\right)$.

Last but not least, in all cases, $\mathrm{R}^{2}$, RMSE, and p-values of the linear regression model revealed that the trends of $\mathrm{E}_{\mathrm{p}}$, PETs, and $\mathrm{ET}_{\mathrm{o}}$ had statistically insignificant and very low correlation with time (see Figure 3-5) [13-16].

\section{Conclusion}

Although potential evapotranspiration according to Haude, Wendling, and Penman (PETs) and reference evapotransipiration $\left(\mathrm{ET}_{\mathrm{o}}\right)$ had shown annual as well as summer half-year decreasing trends, the so-called 'evaporation paradox' had not existed on annual basis because air temperature had not shown increasing annual trend at Tharandt. Class A pan evaporation $\left(\mathrm{E}_{\mathrm{p}}\right.$ ) had shown nearly constant trend for summer half-year. When we had not considered $E_{p}$, indeed, evaporation paradox had existed at Tharandt on the summer half-year based on PETs and ET estimates.

When 2013 was excluded, the annual trend of PETs for the remaining nine years remained decreasing; however, the summer half-year trends of $\mathrm{ET}_{\mathrm{o}}$ and $\mathrm{E}_{\mathrm{p}}$ were changed. Thus, it can be concluded that ten years are not enough to evaluate the summer half-year evaporation paradox on the basis of Class A pan evaporation at Tharandt. Particularly, trend determination of ET and $E_{p}$ needs to be performed over longer time span of more than ten years, if data is available; preferably over 30 years and above as stated by the World Meteorological Organization.
The causes for the nearly 'no trend' of summer half-year $E_{p}$ need further investigations for better explanation because except the trend of air temperature, the trends of shortwave or solar radiation $\left(\mathrm{R}_{\mathrm{s}}\right)$, relative air humidity $(\mathrm{RH})$, and wind speed at $2 \mathrm{~m}$ $\left(u_{2}\right)$ were in favor of a decreasing trend of $E_{p}$.

\section{Acknowledgment}

First of all, I do praise GOD and GOD's Mother above all. I particularly thank Virgin Mary's or 'Tsadiqane Mariam' ('9.:- $\mathbf{P}$; qC,Pq') monastery of Ethiopia. Next, I thank Technische Universität Dresden, Faculty of Environmental Sciences, Institute of Hydrology and Meteorology, Chair of Meteorology for providing me all the data used for the study. I also thank DAAD, the National Meteorology Agency of Ethiopia (NMA), and the Ethiopian Meteorology Society for giving me financial support during my master's study. Very special thanks to my official supervisors Dr. Uta Moderow and Prof. Dr. Christian Bernhofer for their excellent supervision during my master thesis (finished in 2017). I am also grateful to my friend Mr. Abebe Guadie and to my brother's friend Mr. Shambel Abdi; they supported me in the publication of my previous research article. Last but not least, I would like to thank my wife and my family and friends for their crucial support and for sharing love and happiness.

\section{Data Availability Statement}

All data used during the study were provided by a third party. Direct requests for these materials may be made to the provider as indicated in the Acknowledgements. Also, all models or code generated or used during the study are available from the corresponding author by request.

\section{ORCID}

Antensay Mekoya https://orcid.org/0000-0002-2895-4581.

\section{References}

1. Roderick ML, Hobbins MT, Farquhar GD (2009) Pan Evaporation Trends and the Terrestrial Water Balance. I. Principles and Observations. Geography Compass 3/2: 746-760.

2. Zhang Q, Wang W, Wang S, Zhang L (2016) Increasing Trend of Pan Evaporation over the Semiarid Loess Plateau under a Warming Climate. J America Met Soc.

3. Zuo H, Chen B, Wang S, Guo Y, Zuo B, et al. (2016) Observational study on complementary relationship between pan evaporation and actual evapotranspiration and its variation with pan type. Agricultural and Forest Meteorology 222: 1-9.

4. Abtew W, Obeysekera J, Iricanin N (2011) Pan evaporation and potential evapotranspiration trends in South Florida. Hydrol Process 25(6): 958-969.

5. Linacre ET (2004) Evaporation trends. Theor Appl Climatol 79: 11-21. School of Resources, Environment and Society, Australian National University, Canberra, Australia.

6. Brutsaert W, Parlange MB (1998) Hydrologic cycle explains the evaporation paradox. Nature 396: 30 @ Macmillan Publishers Ltd. 
7. Allen RG, Pereira LS, Raes D, Smith M (1998) Crop evapotranspiration: Guidelines for computing crop water requirements.' FAO Irrig. and Drain. Paper No. 56, Food and Agricultural Organization of the United Nations, Rome, Italy.

8. Weiß M, Menzel L (2008) A global comparison of four potential evapotranspiration equations and their relevance to stream flow modelling in semi-arid environments. Adv Geosci 18: 15-23.

9. Wendling U (1991) Schätzmethoden der Verdunstung landwirtschaftlicher Bestände nach den Ansätzen von Penman und Turc." = 'Estimating evaporation in crop stands according to Penman and Turc formulas.' (in German, with English summary). Arch.AckerPflanzenbau Bodenkd. 35: 251-257.

10. ASCE-EWRI (2002) The ASCE Standardized Reference Evapotranspiration Equation Appendices A-F. Environmental and Water Resources Institute (EWRI) of the American Society of Civil Engineers (ASCE) Standardized Reference Evapotranspiration Task Committee (TC).

11. Antensay M, Christian B, U Moderow (2019) Estimation of Evaporation using Daily and Ten-Minute Class-A Pan Data from Automatic
Measuring Pressure Sensor Instrument at Tharandt, Germany. Int J Environ Sci Nat Res 19(1): 556003.

12. Moriasi DN, Arnold GJ, Van Liew MW, Bingner RL, Harmel RD, et al. (2007) Model Evaluation Guidelines for Systematic Quantification of Accuracy in Watershed Simulation. American Society of Agricultural and Biological Engineers 50(3): 885-900.

13. Mohammadi M, Ghahraman B, Davary K, Liaghat AM, Bannaya M (2012) Pan coefficient $\left(\mathrm{K}_{\mathrm{p}}\right)$ estimation under uncertainty on fetch. Meteorol Atmos Phys 117: 73-83.

14. Seiler KP, Gat JR (2007) Groundwater Recharge from Run-off, Infiltration, and Percolation.

15. Weiss A (2009) Beitrag unterschiedlicher Bodenbearbeitungsverfahren und Bewirtschaftungsformen der Landwirtschaft zur Reduzierung des Hochwasserabflusses. ['Kasseler Wasserbau-Mitteilungen Fachgebiet Wasserbau und Wasserwirtschaft Universität Kassel.' Univ.-Prof. Dr.Ing. Stephan Theobald (Hrsg.)].

16. Wittenberg H (2011) Praktische Hydrologie: Grundlagen und Übungen. [Prof. Dr.-Ing. Hartmut Wittenberg].

Your next submission with Juniper Publishers will reach you the below assets

- Quality Editorial service

- Swift Peer Review

- Reprints availability

- E-prints Service

- Manuscript Podcast for convenient understanding

- Global attainment for your research

- Manuscript accessibility in different formats ( Pdf, E-pub, Full Text, Audio)

- Unceasing customer service

Track the below URL for one-step submission https://juniperpublishers.com/online-submission.php 